\title{
ANALISIS KESULITAN PESERTA DALAM MENYUSUN PROPOSAL PTK PADA DJJ PTK BAGI GURU MADRASAH TSANAWIYAH DI BDK JAKARTA
}

\author{
Marina Setiawati \\ Balai Diklat Keagamaan Jakarta, Indonesia \\ setiawatimarina@gmail.com
}

\begin{abstract}
This study aims to identify participants difficulties in writing classroom action research proposals. The population of the research are participants of Classroom Action Research Distance Education consists of 40 MTs Teachers. This research was conducted using a qualitative descriptive research method. The data were obtained through observations on training activity September to November 2016. The study revealed some difficulties. Firstly, in chapter I, the most difficulties were in the formulation of problems and research objectives. In chapter II, the greatest difficulties were found in literature review, finding references, and formulating a research framework. In chapter III, the biggest difficulty was in formulating research procedures. This study recommends an instructional revision, especially in the aspects of learning resources and learning activities.
\end{abstract}

Keywords: DJJ Online; Classroom Action Research; learning difficulties.

\begin{abstract}
Abstrak
Penelitian ini bertujuan untuk mengetahui kesulitan peserta dalam belajar menyuusun proposal PTK pada peserta Diklat Jarak Jauh Penelitian Tindakan Kelas bagi Guru MTs di BDK Jakarta. Penelitian ini dilakukan menggunakan metode penelitian deskriptif kualitatif. Populasi penelitian adalah peserta DJJ PTK bagi Guru MTs. Data dalam penelitian ini diperoleh melalui pengamatan pada proses DJJ PTK bagi guru MTs di BDK Jakarta sejak bulan September s.d November 2016. Hasil pengamatan menunujkkan beberapa kesulitan. Pada penyusunan bab I, kesulitan terbanyak pada perumusan masalah dan tujuan penelitian. Pada penyusunan bab II ditemukan kesulitan terbesar pada penyusunan sistematika kajian pustaka, mencari referensi, dan perumusan kerangka berpikir. Pada penyusunan bab III kesulitan terbesar pada penyusunan prosedur penelitian dan indikator keberhasilan. Penelitian ini merekomendasikan dilakukan revisi istruksional khusunya dalam aspek sumber belajar dan kegiatan belajar.
\end{abstract}

Kata Kunci: Diklat Jarak Jauh; kesulitan belajar; Penelitian Tindakan Kelas. 


\section{PENDAHULUAN}

Publikasi ilmiah adalah salah satu unsur-unsur yang diperlukan untuk memenuhi angka kredit yang dipersyaratkan untuk kenaikan jabatan fungsional guru. Berdasarkan observasi Penulis pada penilaian angka kredit guru golongan IV/a ke IV/b sejak tahun 2013, pada setiap periode penilaian angka kredit guru golongan $\mathrm{IV} / \mathrm{a}$ ke IV/b, hanya sekitar $20 \%$ dari usulan angka kredit guru yang memenuhi nilai publikasi ilmiah yang dibutuhkan yaitu 12 .

Ada 10 macam publikasi ilmiah yang dapat diajukan oleh seorang guru, yaitu presentasi di forum ilmiah, laporan hasil penelitian, makalah tinjauan ilmiah, tulisan ilmiah populer, artikel ilmiah, buku pelajaran, modul/diktat, buku dalam bidang pendidikan, karya terjemahan, dan buku pedoman guru (Kemdikbud, 2010). Namun berdasarkan observasi Penulis pada kegiatan Penilaian Angka Kredit guru golongan IV/a ke IV/b, di antara kesepuluh publikasi ilmiah tersebut yang paling banyak diajukan guru adalah laporan hasil Penelitian Tindakan Kelas (PTK) karena PTK merupakan penelitian yang bermanfaat bagi peningkatan mutu pembelajaran di kelas. Sekarang ini banyak guru yang mengalami stagnasi di golongan IV/a. Mereka kesulitan naik ke golongan IV/b karena terkendala tuntutan untuk memenuhi angka kredit dari unsur publikasi ilmiah khususnya PTK. Bahkan untuk saat ini, mulai dari golongan III/d ke IV/a sudah wajib mengajukan PTK.

Berdasarkan wawancara kepada guru-guru peserta diklat teknis fungsional di BDK Jakarta, ternyata masih banyak guru yang belum mengetahui tentang cara menyusun PTK. Kebanyakan dari guru-guru di wilayah kerjanya baru mengetahui cara menyusun laporan PTK setelah mengikuti mata diklat Penelitian Tindakan Kelas pada diklat fungsional dan diklat substantive, sehingga saat ini diklat adalah sarana yang paling efektif untuk memberikan sosialisasi mengenai penyusunan laporan PTK.

Berdasarkan hal tersebut maka diklat PTK sangat dibutuhkan oleh para guru, sedangkan pelaksanaan diklat PTK sangat terbatas. Agar lebih banyak guru yang dapat memperoleh diklat PTK maka sangat potensial kalau diklat ini disajikan secara distributed melalui DJJ online. Oleh karena itu sejak tahun 2015 di BDK Jakarta dilaksanakan DJJ mata diklat PTK sebanyak 3 angkatan yaitu untuk guruguru MI, MTs, dan MA.

Pelaksanaan Diklat Jarak Jauh (DJJ) di BDK Jakarta dilakukan dengan pengembangan sistem instruksional untuk menciptakan proses belajar yang efektif, efisien, dan menarik. Desain pembelajaran menggunakan desain instruksional model siklus Horton melalui tiga langkah yaitu absorb knowledge, do practices, dan connect to the life and work. DAlam memfasilitasi terjadinya siklus belajar tersebut dalam 
LMS disediakan berbagai kegiatan pembelajaran termasuk di dalamnya konten bahan instruksional, strategi, hingga penilaian. Aktivitas pada online learning diawali dengan peserta menyerap materi pembelajaran dari learning object yang telah disediakan, lalu peserta melakukan diskusi untuk memperdalam pengetahuan melalui diskusi online, selanjutnya peserta mengerjakan tugas yang diberikan tutor. Aktivitas pada pembelajaran secara online ini diharapkan dapat membangun konsep dan kemampuan guru dalam penyusunan proposal PTK (Horton, 2006).

Prinsip pembelajaran yang diterapkan teori situated cognition dan constructivism (Dabbagh, 2005). Contoh strategi pembelajaran yang tepat digunakan adalah collaboration (kolaborasi), articulation (artikulasi), reflection (refleksi), role-playing (bermain peran), exploration (penggalian), dan problem solving (pemecahan masalah).

Selain itu diterapkan model pembelajaran problem base. Menurut Naidhu, strategi pembelajaran yang sesuai dalam aplikasi konsep pembelajaran elektronik antara lain pembelajaran berbasis masalah dan berbasis goal, pembelajaran berbasis kasus, pembelajaran berbasis permainan peran, dan pembelajaran yang didesain (Naidhu, 2006). Dalam pembelajaran berbasis masalah, disajikan sebuah masalah yang telah dikondisikan sebagai sebuah konteks dan tema untuk sebuah kegiatan belajar. Pembelajaran berbasis masalah biasanya diawali dengan presentasi masalah kepada peserta, dapat berupa video pendek, gambar dengan teks, atau hanya teks. Untuk menyelesaikan masalah ini, peserta diharapkan dapat menganalisa dan memutuskan langkah apa yang dapat dilakukan selanjutnya. Pada DJJ PTK di BDK Jakarta peserta belajar menggunakan model Problem Base Instruction (PBI) (O'Grady, Yew, Goh, \& Sshmidth, 2012).

Pada DJJ PTK disajikan materi penyusunan proposal dan pelaporan PTK. DJJ tersebut dibagi menjadi 2 tingkatan. Tingkatan pertama adalah Teknik penyusunan Proposal PTK dan Tingkatan Kedua adalah Teknik Penyusunan Laporan PTK. Yang dimaksud dengan PTK pada DJJ tersebut adalah suatu pencermatan terhadap kegiatan belajar berupa sebuah tindakan, yang sengaja dimunculkan dan terjadi dalam sebuah kelas secara bersama. Tindakan tersebut diberikan oleh guru atau dengan arahan dari guru yang dilakukan oleh siswa (Arikunto, 2006).

Sebelum melakukan penelitian Tindakan Kelas seorang peneliti harus menyusun proposal PTK. Proposal PTK berfungsi untuk menuntun peneliti dalam melaksanakan penelitian. Setelah menyusun proposal guru melakukan tindakan di kelas sesuai dengan rancangan yang telah dijabarkan alam proposal. Selanjutnya guru menyusun laporan penelitian. 
Pada DJJ tingkat pertama yaitu Teknik Penyusunan Prposal, peserta Diklat dipandu untuk berlatih menyusun proposal PTK. Materi diawali dengan diskusi mengenai PTK, diskusi mengenai proposal PTK, berlatih menyusun kerangka proposal PTK; kemdian berlatih menyusun tiga bab proposal yaitu pendahuluan, kajian Pustaka dan metodelogi penelitian. Selain itu diajarkan juga Teknik penyusunan instrument penelitian.

Materi Diklat ini termasuk yang paling sulit diantara DIklat-diklat lainnya yang disajikan dalam DJJ di BDK Jakarta. Sementara para guru sangat antusias untuk mengikuti DIklat ini karena mereka dituntut untuk melakukan penelitian dan menyusun laporannya untuk memperoleh angka kredit dalam kenaikan golongan. Sementara itu Diklat ini membutuhkan intensitas belajar yang tinggi karena melibatkan penalaran. Karena karakter tersebut banyak ditemukan kesulitan pada peserta dalam mengikutinya. Banyak peserta yang mengeluh bahwa materi ini sulit dan waktunya terlalu pedek.

Upaya untuk membantu peserta agar mereka lebih mudah menyelesaika DJJ ini adalah dengan cara menyajikannya lebih sederhana. Upaya tersebut harus dilakukan mulai dari merancang bangun ulang materi, strategi dan media pembelajarannya. Namun demikian dalam merancang bangun ulang tersebut dibutuhkan data yang dapat memberikan petunjuk bagian mana yang harus dirancang ulang.

Untuk kebutuhan tersebut dilakukan sebuah penelitian dengan tujuan mengidentifikasi kesulitankesulitan peserta dalam mengikuti DJJ tersebut. Rumusan masalah pada penelitian ini adalah: Kesulitan apa saja yang dihadapi peserta dalam menyusun proposal PTK pada DJJ PTK bagi guru MTs di BDK Jakarta? Hasil penelitian dapat dimanfaatkan sebagai bahan pertimbangan dan masukan dalam merancang bangun ulang desain DJJ PTK di BDK Jakarta.

\section{METODE}

Penelitian ini menggunakan metode deskriptif kualitatif. Metode penelitian yang digunakan dalam penelitian ini adalah analisis konten dan wawancara.

Subyek penelitian ini adalah peserta DJJ mata diklat PTK bagi Guru MTs sebanyak 35 orang yang diselengarakan September s.d November 2018.

Data utama penelitian ini terdiri dari 2 jenis yaitu tugas-tugas yang dikirim melalui LMS dan hasil wawancara dengan peserta. Selain itu dilakukan telaah terhadap perbicaham (chat) dan diskusi-diskusi informal yang terjadi pada media social yang digunakan pada proses pembelajaran.

Langkah penelitian diawali dengan megunduh tugas-tugas yang dikirim peserta melalui LMS. Selanjutnya menelaah kekeliruan- 
kekeliruan yang cenderung banyak ditemuakan dalam tugas tersebut. Temuan-temuan tersebut selanjtunya dijadikan bahan untuk melakukan wawancara. Rekaman diskusi dan chat di media sosial dijakdikan pendukung data hasil wawancara. Selanjutnya peneliti menelaah hasil wawancara sehingga menemukan kecenderungankecenderungan jawaban terhadap pertanyaan yang diajukan dalam rumusan masalah.

\section{HASIL DAN PEMBAHASAN}

Pada DJJ mata diklat PTK, produk dari peserta adalah proposal PTK. Pada aktivitas menyusun proposal PTK peserta melakukan aktivitas melakukan pra PTK, menyusun bab I, bab II, dan bab III serta insrumen penelitian. Hasil observasi Peneliti terhadap kesulitan peserta DJJ mata diklat PTK tingkat MTs dalam menyusun proposal PTK adalah sebagai berikut:

\section{Kesulitan peserta pada kegiatan Pra PTK}

Sebelum diberi tugas untuk melakukan pra PTK peserta diberi tugas menjawab pertanyaan mengenai apa yang dimaksud pra PTK, kapan dilakukannya, apa yang dilakukan dalam pra PTK, hasil dan manfaat pra PTK. Berdasarkan jawaban 24 orang peserta, pada awalnya masih ada 3 $(12,5 \%)$ orang peserta yang belum memahami kegiatan apa yang dilakukan dalam pra PTK serta manfaat melakukan pra PTK. Kemudian peserta yang belum menjawab dengan benar diminta mempelajari lagi materi yang telah disajikan lalu memperbaiki jawaban. Setelah peserta memahami kegiatan yang dilakukan dalam pra PTK serta manfaat melakukan pra PTK selanjutnya peserta diminta melalukan pra PTK.

Untuk memudahkan guru dalam melakukan pra PTK maka pada tugas berikutnya peserta diberi tugas melakukan pra PTK pada kelas yang diajar di madrasah masing-masing dengan langkah-langkah menggunakan pertanyaan-pertanyaan yang harus dilakukan dalam Pra PTK. Sehingga peserta yang pada awalnya tidak memahami mengenai langkahlangkah yang dilakukan pada pra PTK akhirnya dapat melakukan pra PTK dan mengikuti langkah-langkah ini dengan mudah, Langkah-langkah yang dilakukan peserta, yaitu:

a. Mengidentifikasi masalah

b. Menentukan masalah

c. Mencari bukti-bukti keberadaan masalah

d. Menganalisis daftar penyebab masalah

e. Menentukan penyebab utama

f. Menyusun daftar alternatif tindakan

g. Menentukan pilihan tindakan

h. Membuat rumusan judul

Pada tugas melaksanakan pra PTK ini dari 24 orang peserta DJJ PTK, masih ada 4 orang peserta $(16,6 \%)$ yang mengalami kesulitan dalam melaporkan bukti-bukti keberadaan masalah secara mendetail. Peserta ada 
yang belum mengungkapkan data-data berapa persen siswa yang tidak aktif atau yang belum mencapai nilai KKM.

\section{Kesulitan peserta dalam menyusun bab I}

Pada saat menyusun Bab I, peserta diminta membuat latar belakang masalah. Setelah diberikan kegiatan pra PTK sebagian besar peserta dapat menuliskan latar belakang masalah berdasarkan hasil pada pra PTK. Namun untuk penyusunan "Perumusan Masalah", dari 24 orang peserta masih ada 6 peserta (25\%) yang belum menuliskan dengan benar. Peserta belum membuat rumusan untuk "proses pembelajaran" dan "hasil belajar". Kebanyakan masih merumuskan masalah "hasil" saja. Pada “Tujuan Penelitian", masih ada 7 peserta (29\%) yang tujuan penelitiannya tidak sesuai dengan rumusan masalah. Tutor memberi komentar pada setiap kesalahan peserta dan memberi kesempatan kepada peserta yang masih salah untuk merevisi tulisan bab I nya. Untuk manfaat penelitan, semua peserta sudah menuliskan dengan baik.

\section{Kesulitan peserta dalam menyusun bab II}

Dari 24 orang peserta yang masih bertahan pada kegiatan ini, masih ada 5 orang peserta $(20,8 \%)$ yang belum benar dalam menulis sistematika bab II. Ada 2 orang peserta $(8,3 \%)$ yang referensinya masih kurang, yaitu hanya dari 2 buah buku, ada 3 orang peserta (12,5\%) yang masih lebih banyak menggunakan kutipan dari internet daripada dari buku, dan ada 1 orang peserta (4\%) yang referensinya hanya dari internet. Ada 2 orang peserta yang menuliskan sumber dari kutipan, namun sumber tersebut tidak masuk dalam kajian pustaka karena tidak membaca langsung buku tersebut. Terdapat 7 orang peserta $(29,2 \%)$ yang kesulitan dalam menyusun kerangka berpikir, masih belum dapat menghubungkan variabel-variabel dalam penelitian yaitu apa yang ditingkatkan ("what") dan bagaimana meningkatkannya ("how") dalam penyusunan kerangka berpikir. Selain itu ada 1 orang (4\%) yang masih menulis definisi-definisi dalam kerangka berpikir. Peserta yang masih ada kekurangan dalam proposal bab II selanjutnya memperbaiki sesuai dengan masukan tutor.

4. Kesulitan peserta dalam menyusun bab III

Kebanyakan kesulitan peserta saat menguraikan tentang prosedur penelitian. Ada 3 orang peserta (12,5\%) yang tidak menguraikan sesuai tahapan PTK yaitu perencanaan, tindakan, oservasi, dan refleksi. Pada tahap tindakan masih ada 6 orang peserta $(25 \%)$ yang tidak menguraikan sintaks (tahapan-tahapan pembelajaran) sesuai dengan model pembelajaran yang dipilih. Ada 1 orang peserta $(4 \%)$ yang memasukkan RPP pada tindakan, padahal seharusnya RPP diletakkan di lampiran. Selain itu ada 3 orang peserta $(12,5 \%)$ yang masih belum tepat menentukan teknik pengumpulan data, 
yaitu tidak sesuai antara rumusan masalah dengan teknik pengumpulan data.

Begitu juga dalam menentukan instrument penelitian masih ada 1 orang peserta $(4 \%)$ yang belum tepat antara teknik pengumpulan data dengan instrument yang digunakan. Misalnya bila pengumpulan data dengan observasi maka instrumennya seharusnya dengan lembar observasi. Dalam hal menuliskan indikator keberhasilan pada akhir bab 3 masih ada 4 orang peserta (16\%) belum dapat menuliskannya.

5. Kesulitan peserta dalam menyusun instrument penelitian

Pada tugas penyusunan instrument penelitian, kesalahan terbanyak adalah peserta hanya membuat instrument hasil belajar tidak membuat lembar pengamatan guru dan siswa sebanyak 12 orang (50\%). Selanjutnya kesulitan peserta juga pada penentuan indikator untuk instrumen motivasi dan membuat butir- pernyataannya sebanyak 6 orang (25\%).

Berdasarkan hasil observasi pada aktivitas menyusun proposal PTK (melakukan pra PTK, menyusun bab I, bab II, dan bab III serta insrumen penelitian) di atas, ditemui masih ada peserta yang masih salah dalam mengerjakan tugas yang diberikan. Hal ini tampak dari hasil yang dikirimkan oleh peserta.

Pada penyusunan bab I, kesulitan peserta pada perumusan masalah dan tujuan penelitian. Pada perumusan masalah dan tujuan seharusnya peserta membuat pertanyaan tentang proses pembelajaran bukan hanya tentang hasil belajar karena pada PTK harus diamati tiap pertemuan oleh observer. Peneliti harus mendapat data tentang proses pembelajaran agar mengetahui apakah terjadi peningkatan performans peserta didik pada tiap pertemuan. Kesulitan peserta disebabkan karena kurang teliti dalam membaca bahan ajar yang telah disajikan di web DJJ atau ada yang membaca tapi kurang dapat memahaminya.

Pada penyusunan bab II, kesulitan peserta pada penulisan sistematika. Sebanyak 5 orang peserta $(20,8 \%)$ yang belum benar dalam menulis sistematika bab II adalah mengkaji istilah-istilah di luar variabel. Pada kajian pustaka yang dikaji seharusnya adalah variabel "what" ( apa yang ditingkatkan) dan bagaimana meningkatkannya (“how”). Kesulitan peserta disebabkan karena kurang teliti dalam membaca bahan ajar yang telah disajikan di web DJJ karena sudah ada penjelasan mengenai cara menyusun sistematika KajianPustaka pada bab II atau ada yang membaca tapi kurang dapat memahaminya.

Masih ada peserta yang kesulitan untuk mencari referensi, yaitu ada 1 orang yang referensinya hanya dari 2 buah buku, ada 3 orang peserta $(12,5 \%)$ yang masih lebih banyak menggunakan kutipan dari internet daripada dari buku, ada 1 orang peserta $(4 \%)$ yang referensinya hanya 
dari internet, dan ada 2 orang peserta $(8 \%)$ yang menuliskan sumber dari kutipan, namun sumber tersebut tidak masuk dalam kajian pustaka karena tidak membaca langsung buku tersebut. Kesulitan dalam mencari referensi disebabkan karena peserta kurang menggunakan buku sebagai referensi, guru tidak memiliki koleksi buku-buku pendidikan, untuk membeli memerlukan biaya dan waktu karena jauh dari tempat kerja dan tempat tinggal, sehingga guru lebih mudah mencari referensi dari internet. Kelemahan mengambil referensi dari blog adalah banyak blog yang belum berkualitas, kadang bahasanya menggunakan bahasa popular, ada pula tidak menuliskan sumbernya jika mengutip sehingga tidak diketahui dari mana sumbernya. Seharusnya peserta atau guru pada umumnya dapat memilih blog-blog mana yang bisa digunakan sebagai referensi yang baik. Madrasah seharusnya juga menyediakan buku-buku pendidikan untuk guru-gurunya di perpustakaan madrasah agar guru-gurunya dapat memanfaatkan untuk penelitian.

Dalam menyusun kerangka berpikir terdapat 7 orang peserta $(29,2 \%)$ yang masih belum dapat menghubungkan variabel-variabel dalam penelitian yaitu apa yang ditingkatkan ("what") dan bagaimana meningkatkannya ("how") dan ada 1 orang (4\%) yang masih menulis definisidefinisi dalam kerangka berpikir. Untuk kemampuan ini memerlukan ketekunan dan harus banyak membaca penelitianpenelitian orang lain seperti skripsi/tesis/disertasi atau jurnaljurnal, sehingga guru dapat mempelajari bagaimana menuliskan kerangka berpikir yang baik.

Kesulitan peserta pada dalam penyusunan proposal bab III, yaitu 3 orang peserta (12,5\%) tidak menguraikan sesuai tahapan PTK yaitu perencanaan, tindakan, oservasi, dan refleksi, pada tahap tindakan (acting) masih ada 6 orang peserta (25\%) yang tidak menguraikan sintaks (tahapantahapan pembelajaran) sesuai dengan model pembelajaran yang dipilih, dan 1 orang peserta (4\%) yang memasukkan RPP pada tindakan bukan di lampiran. Kesulitan ini disebabkan karena guru kurang mempelajari materi yang telah disajikan di web, atau ada yang membaca tapi kurang dapat memahaminya sehingga ada kesalahan dalam penyusunan prosedur peneitian. Selain itu ada 3 orang peserta (12,5\%) yang masih belum tepat menentukan teknik pengumpulan data, yaitu tidak sesuai antara rumusan masalah dengan teknik pengumpulan data. Kesalahan ini disebabkan karena guru kurang mempelajari materi yang telah disajikan di kegiatan belajar, atau ada yang membaca tapi kurang dapat memahaminya.

Kesulitan dalam menyusun instrument PTK yaitu peserta hanya membuat instrument hasil belajar tidak membuat lembar pengamatan guru 
dan siswa sebanyak 12 orang (50\%). Hal ini juga disebabkan karena guru kurang mempelajari materi yang telah disajikan di kegiatan belajar, atau ada yang membaca tapi kurang dapat memahaminya. Selanjutnya kesulitan peserta juga pada penentuan indikator untuk instrumen motivasi dan membuat butir- pernyataannya sebanyak 6 orang (25\%). Kesulitan ini dapat diatasi dengan banyak membaca buku-buku tentang penyusunan instrumen.

Setelah melihat kesulitankesulitan peserta seperti di atas, Penulis mencoba mengidentifikasi penyebabnya yaitu:

1. Peserta tidak membaca materi yang telah disajikan oleh tutor karena ingin cepat menyelesaikan tugasnya.

2. Bahan ajar yang disajikan kurang jelas.

3. Bahan ajar yang disajikan kurang menarik.

4. Terlalu banyak tahapan dalam kegiatan belajar, sehingga peserta jenuh.

5. Peserta kurang membaca bukubuku pendidikan sehingga kesulitan dalam menyusun kalimat dan dalam menyusun kajian pustaka.

6. Peserta tidak mengerjakan dengan sungguh-sungguh atau banyak pekerjaan di madrasahnya.

Hal-hal di atas akan menjadi bahan pertimbangan bagi tutor dalam menyusun aktivitas pembelajaran untuk DJJ mata diklat PTK pada tahun depan.

Selain kesulitan-kesulitan yang ditemui pada tataran materi dan strategi banyak penelitian yang menjelaskan kesulitan-kesulitan yang dialami peserta pelatihan online pada orang dewasa. Salah satunya adalah kecemasan (anxiety). Kecemasan sangat mengganggu pembelajaran orang dewsa dalam mengikuti DJJ. Beberapa penyebab kecemasan loss of learning skills, kurangnya pengalaman dalam mengikuti belajar jarak jauh kurang dukungan dari lingkungannya (Pozdnyakova \& Pozdnyakova, 2016).

Selain itu peserta PJJ Online mendapat beberapa tantangan dalam mengikuti pembelajaran online. Tantangan yang dimaksud terdiri dari tiga kelompok yaitu management challenge, leaning challenge dan technical challenge. Yang dimaksud dengan management challenge adalah tantangan rendahnya kemampuan mengelola diri termasuk didalmya kemampuan menyeimbangkan kepentingan belajar dan pekerjaan, kemampuan menyeimbangkan belajar dengan keluarga, dan kesulitan mengatur waktu. Learning challenge termasuk didalamnya penguasaan pengetahuan dasar, kurang percaya diri, kurang konsentrasi, kesulitan memahami materi, kurang tertarik terhadap materi dan kurangnya komitmen belajar. Sedangkan tantangan teknis meliputi rendahnya kemampuan penggunaan 
ICT (Kara, Erdogu, Kokoc, \& Cagiltay, 2019).

Pappas mengidentifikasi enam kendala pada orang dewasa dalam mengikuti pembelajaran online. Keenam kendala tersebut yaitu sikap instruktur, keterbatasan fisik, menurunnya daya ingat (kapasitas memori), materi ajar, terlalu dewasa untuk beajar dan kekurangan dalam penguasaan ICT (Pappas, 2018).

Referensi-referensi pada paparan di atas menjelaskan kesulitan umum yang ditemua oleh pembelajaran orang dewsa (adult learner) dalam mengikuti pembelajaran online. Kesulitankesulitan belajar online pada orang dewasa tersebut menyatu ada kaitannya dengan kesuitan-kesulitan belajar dalam menyusun proposal pada DJJ seperti dipaparkan pada temuan di atas.

Untuk mengatasi kesulitankesulitan tersebut dibutuhkan strategi yang tepat. Berdasarkan penelitian terdapat beberapa predikor faktorfaktor yang dapat memberikan kepuasan terhadap pembelajaran online orang dewasa. Prediktor kepuasan tersebut dapat mengurangi kendalakendala belajar yang mereka temui. Beberapa predictor diantaranya learning content (bahan ajar), course design (desain pembelajaran), instructor (instruktur.widyaiswara/tutor), social presence (komunitas belajar), instructor presence and learning support (kehadira instruktur dan pendukung belajar ( $\mathrm{Ng}$ \& Baharom, 2018). Faktor-faktor tersebut harus dipertimbangkan dan dirancang sesuai dengan karakter peserta.

\section{KESIMPULAN}

Pada penyusunan bab I ditemukan kesulitan terbanyak pada perumusan masalah dan tujuan penelitian. Pada penyusunan bab II ditemukan kesulitan terbesar pada sistematika penulisan, mencari referensi, dan perumusan kerangka berpikir. Pada penyusunan bab III kesulitan terbesar pada penyusunan prosedur penelitian dan indikator keberhasilan. Kesulitan ini disebabkan karena peserta masih kurang membaca referensi baik yang sudah disajikan di web DJJ maupun buku-buku lain atau peserta kurang memahami apa yang sudah dibacanya.

Pernyataan-pernyataan dalam kesimpulan harus ilmiah sesuai dengan data dan pembahasan. Kalimat kesimpulan tidak boleh mengulangi pernyataan yang termuat dalam abstrak.

Berdasarkan hasik penelitian disarkankan agar dialkukan revisi isntruksional dalam DJJ PTK kususnya dalam kelangkapan dan keberfungsian bahan ajar.

Untuk menanggulangi kesulitankesulitan tersebut harus dilakukan ptbaikan terhadap faktor-faktor yang menyebabkan kesulitan-kesulitan. Faktor yang dimaksud adalah desain instruksional, materi ajar, strategi pembelajaran, media pembelajaran, perilaku instruktur dan komunikasi 
Wawasan

Jurnal Balai Diklat Keagamaan Jakarta p-ISSN 2548-9232; E-ISSN ...

Volume 1 Nomor 1 Tahun 2020

antara peserta dengan peserta serta isnruktur.

komunikasi antara peserta dengan

\section{DAFTAR PUSTAKA}

Arikunto, S. (2006). Penelitian Tindakan Kelas (Edisi Revisi). Jakarta: Bumi Aksara.

Dabbagh, N. (2005). Online Learning: Concept, Strategies and Aplication . New Jersey: Pearson Education.

Horton, W. (2006). e-Learning by Design. San Francisco: Pfeiffer.

Kara, M., Erdogu, F., Kokoc, M., \& Cagiltay, K. (2019). Challenges Faced by Adult Learners in Online Distance Education: A Literature Review. Open Praxis, 5-22.

Kemdikbud. (2010, Mei 6). Permendikbud Nomor 35 tahun 2010. Petunjunk Teknis Pelaksanaan Jabatan Fungsional Guru dan ANgka Kreditnya. Jakarta, Indnesia: Kemdikbud dan BKN.

Kemdikbud. (2016). Panduan PKB. Jakarta: Kemdikbud.

Naidhu. (2006). E-Learning: A Guidebook of Priciples, Procedures and Practices. Melbourne: Commonweath Education Media Center for Asia.

Ng, H. Z., \& Baharom, S. S. (2018). An Analysis on Adult Learners' Satisfaction in . International Journal of Interactive Mobile Technology, 70-85.

O'Grady, G., Yew, E. H., Goh, K. P., \& Sshmidth, H. (2012). One-Day, One-Problem. New York : Springer.

Pappas, C. (2018, Februari 2). Instructional Design. Retrieved from eLearning Industry: 2018

Pozdnyakova, O., \& Pozdnyakova, A. (2016). Adult Students' Problems in the Distance Learning. 6th Conference on Reliability and Statistics in Transportation and Communication, RelStat'2016, 19-22 October, 2016, Riga, Latvia (pp. 243-248). Riga: Science Direct. 